\title{
Pituitary Abnormalization of Mice (Mus Musculus) with Exposure to Kretek cigarette
}

\author{
Jamhariyah,SST.,M.Kes \\ Lecturer in Health Polytechnic of Malang, Republic of Indonesia
}

\begin{abstract}
This research aims to study the effects of kretek cigarette smoke exposure on pituitary abnormalizationof mice (mus musculus). This research was a laboratory experiment with post test experimental and control group design (posttest only control group design). The study was conducted in subjects with various dose of smoke on Group $K$ as a control group without given any cigarette. The treatment group $(P) P 1$ is divided into groups given cigarette smoke of 1 dose/24 hours. P2 group was given 2 cigarette smoke dosage/24 hours. P3 group was given smoke of 3 dosage/24 hours. Treatment for groups P1 through P4 was given once a day. Surgery is performed after the 12th day with the goal oftaking their pituitary. The results of this surgery were used to see their morphology of pituitary. The results of the examination of the three treatment groups were compared with the control group. 28 samples of mice were divided into 4 groups where each group consisted of 7 experimental animals. The samples were taken randomly.
\end{abstract}

Keywords : pituitary abnormalization, tobacco smoke exposure

\section{Introduction}

Healthy reproduction system is expected by all human beings, especially women. Healthy reproduction is identical to the image of women, because if a couple has no children, the stigma of society usually put women to blame. Women's reproductive health is determined by the condition of their reproductive organs. Pituitary as one of the reproductive organs plays an important role in women's reproductive health. Today, there are many women experience problems associated with pituitary conditions, such as menstrual disorders, pituitary polyps, endometriosis, abortion, to cancer. Pituitary can function well when angiogenesis takes place in accordance with the reproductive cycle. Pituitary abnormalization is the process of blood vessel formation in the pituitary. The process of new blood vessel formation is strongly influenced by pecan vascular endothelial growth factor (VEGF) (Ferrara and Davis-Smyth, 1997). Pituitary disorders or angiogenesis disorders can affect pituitary function or can cause infertility. Pituitary function is affected by the secretion of the estrogen and progesterone hormones. Eugene (2002) study found that estrogen increases the incidence of Pituitary Abnormalization. Fertility problems prevalence in the world is one of seven couples in every year. Infertile couples in Indonesia in 2009 reaches the number of 50 million couples, or about 15-20\% (Ina soengkowo, 2009).

Research by Kelly (2006) found out that angiogenesis pituitary disorders can be caused by lifestyle such as age, history of ectopic pregnancy, obesity, and smoking. Smoking today is becoming a very familiar sight. Smoking habit gives pleasure to the smoker, but on the other hand it can cause negative effects for the smokers themselves and those around him. The impact is more severe when the person himself is a smoker. Cigarette with toxic substances content is one of the factors that influence the secretion of estrogen. Direct toxic effects of tobacco smoke are still unclear. Therefore, researchers wanted to examine how the effects of cigarette smoke exposure on women's angiogenesis.

Some researchers suspect that the smoke has the effect of lowering the risk of the possibility of pituitary cancer. This is presumably due to smoking allegedly reduces the production of estrogen and also their anti estrogenic effects of smoking. Another theory is that smoking affects the absorption, metabolism and distribution of estrogen. Smoking is also believed to alter more estrogen into 2-hidroksiestrone that has low estrogenic effect. Based on the research background, the researcher will try to find out about pituitary abnormalization on mice (Mus musculus) with exposure to cigarette smoke?

\section{General Objective}

This research generally aims to study the effects of cigarette smoke exposure on Pituitary Abnormalizationof mice (Mus musculus).

\section{Specific Objectives}

In particular, this study aims to:

1. Study pituitary abnormalization on mice (Mus musculus).

2. Study pituitary abnormalization on mice (Mus musculus) with exposure to cigarette smoke.

3. Analyze the effects of cigarette smoke exposure on pituitary abnormalization on mice (Mus musculus). 
Hyphotesis

There are differences between pituitary abnormalization in mice (Mus muskulus) with exposure to cigarette smoke.

\section{Framework}

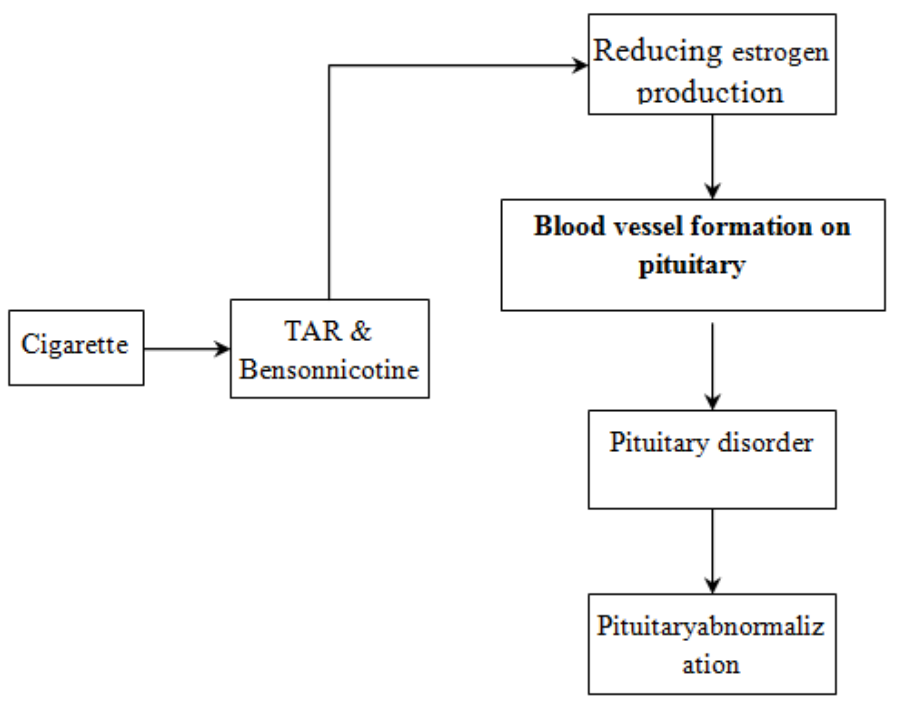

Figure 1.Framework

\section{Method and Design}

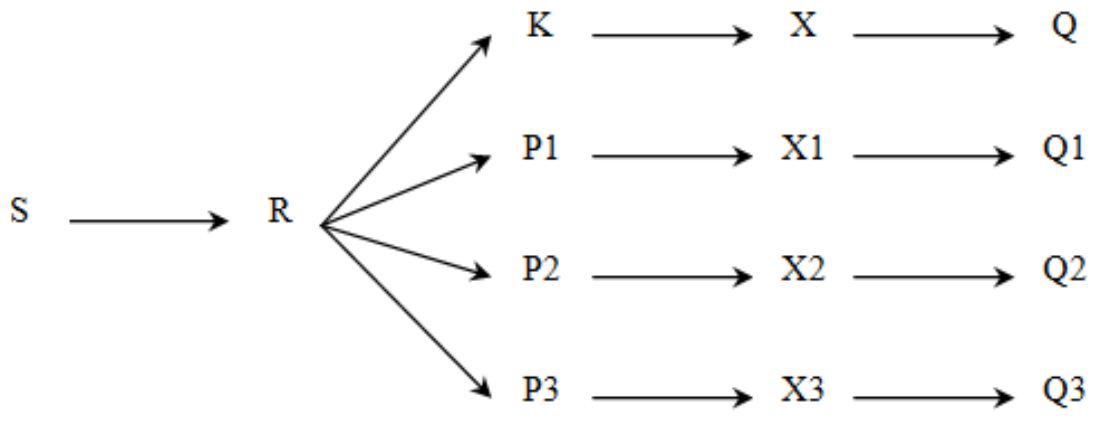

Figure2. Research Plan Chart

Description:

S: Sample

R: Randomization

$\mathrm{K}:$ Control group givenaromatherapy

P1 : Treatment group I, mice were given 1 dose of smoke/24 hours

P2 : Treatment group II, mice were given 2 dose of smoke/24 hours

P3 : Treatment group III, mice were given 3 dose of smoke/24 hours

$\mathrm{X} 1$ : $\quad$ Treatment I

$\mathrm{X} 2$ : $\quad$ Treatment II

X3 : $\quad$ Treatment III

Q : The results of the control treatment

Q1 : Results of Treatment I

Q2 : Results of Treatment II

Q3 : $\quad$ Results of Treatment III

This research is a laboratory experiment with post-test design experimental and control groups (posttest only control group design)). The design can be described as follows: The study was conducted in subjects with a variety of cigarette smoke on Group $\mathrm{K}$ as the control group was given aromatherapy. P1 group was given a cigarette smoke of 1 pack/24 hours. P2 group was given cigarette smoke of 2 packs/24 hours. P3 group was given cigarette smoke of 3 packs/24 hour treatment. P1 until P3 group is given once a day. After 12 days, their pituitary were taken out. They were used to examine the morphology of pituitary thickness. The results of the fourth examination of the treatment group then compared with the control group. 


\section{Experiment Unit and Replication}

The experimental units are chosen mice that meet the following requirements:

1. The age is about $8-10$ weeks

2. Experience in giving birth

3. Female

4. Healthy, which can be seen from their active movement

The amount of sample is determined by Cochran formula replication (1986) defined as follows:

$$
\begin{aligned}
& (\mathrm{t}-1)(\mathrm{r}-1)>20 \\
& (4-1)(\mathrm{r}-1)>20 \\
& 3(\mathrm{r}-1)>20 \\
& 3 \mathrm{r}-3>20 \\
& 3 \mathrm{r} \geq 23 \\
& \mathrm{r} \geq 7
\end{aligned}
$$

Based on the calculation results, it was found out that 28 mice as samples were divided into 4 groups where each group consisted of 7 guinea pigs. Random sampling technique was used.

\section{Research Variable}

Variable Classification

1. Independent variable

a. Cigarette smoke of 1 dose/ 24 hours

b. Cigarette smoke of 2 dose/24 hours

c. Cigarette smoke 3 dos / 24 hours

2. Dependent variable :Pituitary Abnormalization

3. Control variable:
a. Guinea pig type
b. Sex
c. Gestation
d. Age
e. Guinea pigs care and feeding
f. Physical health
g. Sanitation
h. Drinking water
i. Treatment time

\section{Result}

\section{Result and Discussion}

\section{Descriptive Analysis Results}

Descriptive analysis for the number of pituitary cells of mice with cigarette smoke exposure is presented in the following table:

Table 3.1 The average value and standard deviation of the number of pituitary cells of mice with exposure to cigarette smoke

\begin{tabular}{|c|c|c|c|c|c|}
\hline \multirow{2}{*}{ Number of cells } & \multirow{2}{*}{ Size } & \multicolumn{4}{|c|}{ Cigarette smoke exposure } \\
\cline { 3 - 6 } & Control & $\begin{array}{c}\text { 1 piece/ } \\
24 \text { hours }\end{array}$ & $\begin{array}{c}2 \text { pieces/ } \\
24 \text { hours }\end{array}$ & $\begin{array}{c}3 \text { pieces/ } \\
24 \text { hours }\end{array}$ \\
\hline \multirow{2}{*}{ Pituitary } & Average & 103.75 & 96.88 & 93.38 & 89.63 \\
\cline { 2 - 6 } & $\begin{array}{c}\text { Deviation } \\
\text { standard }\end{array}$ & 9.362 & 8.149 & 9.942 & 7.110 \\
\cline { 2 - 6 } & $\mathrm{n}$ & 8 & 8 & 8 & 8 \\
\hline
\end{tabular}

Table 3.1 above shows that the control treatment had the highest average number of pituitary cells, with the value of 103.75 with a standard deviation of 9.362.Meanwhile the group with cigarette smoke exposure treatment tends to show decreasing number of pituitary cells. In exposure to cigarette smoke treatment as much as 1 piece/24 hours, the average number of pituitary cells reach to 96.88 with a standard deviation of 8.149 , the treatment with cigarette smoke exposure as much as 2 pieces/24 hours reach the average number of 93.38 pituitary cells with standard deviation of 9.942 and treatment with exposure to cigarette smoke as much as 3 packs/24 hours reach the average number of pituitary cells of 89.63 with a standard deviation of 7.110.

Provision of cigarette smoke exposure resulted in a decrease in the number of pituitary cells of mice. The average number of pituitary cells in cigarette smoke exposure is presented on the following figure: 


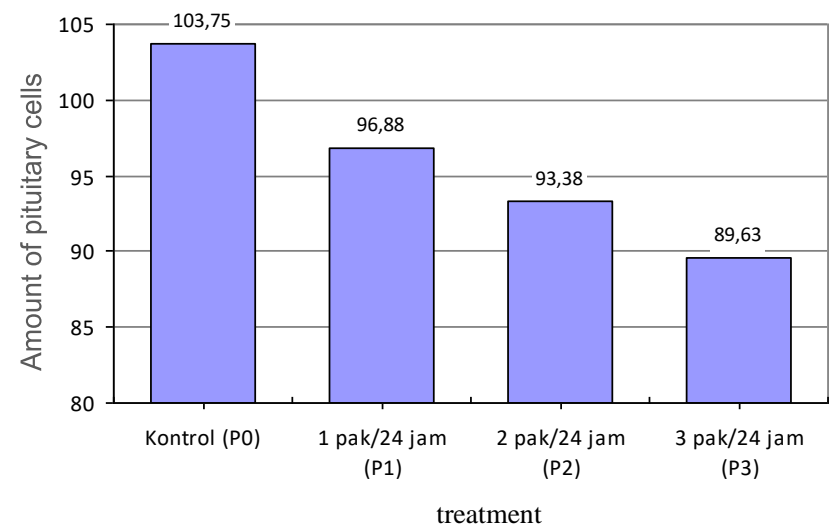

Figure 3.1 Histogram about the average number of pituitary cells of mice with various treatment of exposure to cigarette smoke

Results of significant difference test on the number of follicles

It is used to determine the median score among the treatment groups with exposure to cigarette smoke which gives different effects on the number of pituitary cells of mice. Based on the data of normality test used in this study with single factor ANOVA (One-way Anova), the first factor of exposure was cigarette smoke.

\section{Results of Analysis of variance treatment of cigarette smoke exposure on the number of pituitary cells}

Table 3.2 Results of univariate ANOVA test on the number of pituitary cells of mice with exposure to cigarette

\begin{tabular}{|l|l|l|l|l|l|l|}
\hline Source of Variance & $\begin{array}{c}\text { Number of } \\
\text { Quadrate }\end{array}$ & $\begin{array}{c}\text { Degree of } \\
\text { Freedom }\end{array}$ & $\begin{array}{c}\text { Mid } \\
\text { Quadrant }\end{array}$ & F-count & Sign. & Note \\
\hline Treatment & 866.594 & 3 & 288.865 & 3.808 & 0.021 & Significant \\
Error & 2124.125 & 28 & 75.862 & & & \\
Total & 2990.719 & 31 & & & & \\
\hline
\end{tabular}

Based on the table above, in One-way Anova, the number of pituitary cells of mice treated with exposure to cigarette smoke showed significant effect on the number of pituitary cells with F-count value of 3.808 and a significance of 0.021.The test followed with Tukey-HSD test for One-way Anova test with a significant difference between the treatment of cigarette smoke exposure on the number of pituitary cells. The test results of Tukey-HSD on the number of pituitary cells which was influenced by cigarette smoke exposure treatment are presented in Table 3.2.

Table 3.3.Tukey HSD test results on the number of pituitary cells of mice that were treated with cigarette smoke exposure

\begin{tabular}{|l|cl|}
\hline Kretek Cigarette Smoke Exposure & \multicolumn{3}{|c|}{ Number of Pituitary Cells } \\
\hline Control & 103.75 & $\mathrm{a}$ \\
\hline 1 piece/24 hours (P1) & 96.88 & $\mathrm{ab}$ \\
\hline 2 pieces/24 hours (P2) & 93.38 & $\mathrm{ab}$ \\
\hline 3 pieces/24 hours (P3) & 89.63 & $\mathrm{~b}$ \\
\hline
\end{tabular}

According to the table above, HSD-Tukey test results on the number of pituitary cells influenced by cigarette smoke exposure showed that the control treatment $(\mathrm{P} 0)$ had no significant difference with those treated with kretek cigarette smoke exposure of 1 piece/24 hours (P1) and with 2 pieces/24 hours ( P2), but it is significantly different from the treatment with cigarette smoke exposure of 3 pieces/24 hours (P3). While those treated with 1 piece/24 hours (P1) cigarette smoke exposure, 2 pieces/24 hours (P2) and 3 pieces/24 hours (P3) are not significantly different. The lowest number of pituitary cells generated by cigarette smoke exposure treatment at a dose of 3 packs/24 hours (P3) is 89.63 pituitary cells in average.

\section{Discussion}

Based on the results of the research and data analysis, the male mice given the treatment of exposure to cigarette smoke 3 pieces/ 24 hours showed a decrease in the number of pituitary cells after being examined by histopathology (Table 4.1 and Figure 3.3). Decreasing amount of pituitary cells is obtained after calculating the mean of pituitary cells in control group with the average amount of pituitary cells in the treatment groups showed significant difference statistically. This is caused by the degeneration of pituitary cells by the influence of toxic chemical agents found in cigarette smoke that are given continuously in a long time. The above is in 
accordance with several studies on the effects of the compounds contained in cigarette smoke that has negative effects such as inhibiting spermatogenesis, damaging even to cause the death of cells in the reproductive organs. Archibong et al. (2008) stated that the administration of PAH compounds for 60 days can lead to atrophy of the seminiferous tubules, sperm morphology damage, reduce levels of the hormone progesterone and LH. Revel et al. (2001) stated that mice exposed to B (a) P suffered DNA damage and increased cell apoptosis of spermatogonia and is supported by the results of Bizzarro et al. (2003) on the mice that received the lead by gavage showed disruption of spermatogenesis and DNA Sertoli cell damage.

Based on the description above it can be said that the damaged cells found in the female reproductive organs are not only caused by the nicotine in cigarette smoke. It is because cigarette smoke still contains other harmful chemicals. Cigarette smoke is also the source of free radicals that can cause damage to cells in three ways, which is called peroxidation lipid components of the cell membrane and cytosol, which lead to a series of reduction of fatty acids (autocatalysis) which resulted in damage to the membrane and organs of cells, damaging DNA resulting in DNA mutations even cell death and oxidized protein modification, because the formation of a cross-linking proteins through the sulfhydryl mediator on several labile amino acids such as cysteine, methionine, lysine and histidine (Eberhardt, 2001; Kumar et al., 2003).

The pituitary gland is very important for conveying messages from the brain in a way that is called as the hypothalamus gland and utilize these messages to produce hormones that affect different parts of the body and activate all other hormonal glands to produce their own hormones. This is the reason why it is called the "master gland". According to Chen and Zirkin (2009) a decrease in the number of pituitary cells of the testis can be influenced by age, as someone gets older, Leydig cells also causes abnormal structures as well as decreasing. The declining number of pituitary cells are also influenced by external factors such as exposure to toxic chemicals from cigarette smoke that has a direct negative effect on the cell or tissue in the testis in accordance with the results obtained in this study. This is also in line with the statement from Trummer, et al., (2002) that inhaling cigarette smoke either actively or passively, will be followed by absorption of substances in the smoke by the blood vessels in the lungs and circulate in the blood circulation and allows the deposition of the toxic substance in seminal plasma through various means such as diffusion and active transfer. These substances ultimately induce cell death (apoptosis) as occurs in the pituitary cells.

Follicle-stimulating hormone (FSH) is a glycoprotein gonadotropin secreted by the anterior pituitary in response to gonadotropin-releasing hormone $(\mathrm{GnRH})$ released by the hypothalamus. The pituitary gland also secretes luteinizing hormone (LH), which is another type of gonadotropin. FSH and LH is composed of alpha and beta subunits. Certain beta subunit confers unique biological activity. FSH and LH bind to receptors in the testes and ovaries and regulate gonadal function by encouraging the production of sex steroids and gametogenesis. The decrease in the number of pituitary cells in female mice that receive treatment of exposure to cigarette smoke.

\section{Conclusion}

\section{Conclusion and Recommendation}

Based on the description above, it can be concluded that:

1. Kretek cigarette smoke exposure decreases the amount of pituitary cells.

2. There is a significant difference between some kretek cigarette smoke exposure with the control group.

\section{Recommendation}

Further research must be conducted about the effectiveness of progesteron hormone therapy to recover the amount of pituitary cells in different doses and variables suitable with its development phase so that specific level of its recovery can occur specifically.

\section{References}

[1]. Campbell DT dan Stanley JC, 2003. Experimental Design for Research Rand. Chicago : Mc Nally College Publishing Company.

[2]. Cochran W.G, 2001. Teknik Penarikan Sampel, Edisi Ketiga. Terjemahan Rusdiansyah. Jakarta : Penerbit Universitas Indonesia.

[3]. Dorland, 2005, Kamus Kedokteran, Edisi ke dua puluh delapan, EGC, Jakarta. Hal 726 - 727.

[4]. Ganong WF, 2010. Review of Medical Physiology, $19^{\text {th }}$ ed. Stand Ford Connecticut:

[5]. Ganong, WF. 2003, Buku Ajar Fisiologi Kedokteran, Edisi 20, EGC, Jakarta Hal. 417-431.

[6]. Greenspand FS and Forshan PH, 1997. Basic and Clinical Endocrinology, $5^{\text {th }}$ ed. Stand Ford Connecticut : Appleton and Large, pp 545-567.

[7]. Guyton dan Hall, 2007, Buku Ajar Fisiologi Kedokteran Cetakan 1, EGC, Jakarta, Hal; 1283-1302.

[8]. Hardjo Pronjoto, 1995. Ilmu Kemajiran Ternak. Surabaya: AirlanggaUniversity Press.

[9]. Heyne K, 2007. Tumbuhan Berguna Indonesia, Jilid 11. Jakarta : Badan Penelitian dan Pengembangan KehutananRI, hlm 840-842.

[10]. Hunter RHF, 2003. Fisiologi dan Teknologi Reproduksi Hewan Betina Domestik. Bandung: Penerbit ITB.

[11]. Ismudiono, 1999. Embriologi Reproduksi pada Ternak. Surabaya: FKH Universitas Airlangga.

[12]. Johnson M, 1995. Essential Reproduction, $4^{\text {th }}$ Edition. London: Department of Embriology and Department of Experimental of Psychology University of Cambridge. 
[13]. Limbong T, 2004, Pengawas Ekstrak Etanol Kulit Batang Batangettu (Ficus superbamiq) Terhadap Foklulogenesis Ovarium Mencit (Mus musculus) Tesis, Universitas Airlangga Surabaya.

[14]. Marge K, Judith T and Gay, 2007. Kesehatan Wanita. Yogyakarta: Universitas Gajah Mada.

[15]. Mursito B, 2004. Ramuan Tradisional untuk Kesehatan Ibu Hamil. Jakarta Penerbit Swadaya.

[16]. Partodihardjo S, 2002. Ilmu Reproduksi Hewan. Jakarta: Penerbit Mutiara, h1m 43-52; 105-108; 173-181.

[17]. Prawirohardjo, 1991. llmu Kebidanan, Cetakan Kelima. Yayasan Bina Pustaka Sarwono, Hal; 64-85.

[18]. Purnomo SM, 2002. Pengembangan Obat Tradisional dalam Dunia Pengobatan. Surabaya: Kanwil Depkes Propinsi Jawa Timur.

[19]. Sarwono, 2004. Ilmu Kandungan. Jakarta: Yayasan Bina Pustaka Sarwono Prawirohardjo, hlm 544-545: 634-643.

[20]. Speroff L, MD and Phillip D, 1996. A Clinical Guide for Contraception, 22 ${ }^{\text {nd }}$ edition. San Francisco: University of California, pp 35-37.

[21]. Speroff L, Robert H, and Nathan GK, 2005. Clinical Embriology Gynecology Endocrinology and Infertility, $5^{\text {th }}$ edition. BaltimoreLondon: William and Williams Co, pp 76-85.

[22]. Tambajong J, 2009, Buku Ajar Histology, EGC, Jakarta, Hal; 480-509.

[23]. Verralls S, 2003, Anatomi dan Fisiologi Terapan Dalam Kebidanan, Edisi 3. Jakarta, EGC, Hal; 161-173. 